and can be expected to be acceptable only if the features and dynamics of the effective power process have changed.

It is understandable that states denied the veto privilege in an organized arena should chafe at their disability and seek to minimize its legal effect. But it is, to say the least, surprising to find states with the veto consciously undertaking to minimize its effect in order to achieve short-term and quite transient objectives. It is especially disconcerting when the denigration of the veto is not necessary to achieve those ends.

When wielded by adversaries, the veto has worked against the United States. But in a curious way it may have preserved the United Nations by allowing or forcing it to yield to reality. As the relative influence of the United States in the General Assembly has waned, the veto has increasingly served American interests. Indeed, it may now contribute to the ability of the United States to continue to be an active supporter of the Organization. Departures from the veto regime, such as the General Assembly's "Uniting for Peace" Resolution" (an American initiative), in retrospect are viewed by many in the foreign affairs establishment with very mixed feelings.

Obviously, none of the permanent members of the Security Council is about to surrender the veto. But careless language can erode its effectiveness. Some stand to gain much more than others by the addition of a Security Council majoritarian system that ascribes some legal power to impurtant questions even after they have been vetoed. The United States and Western Europe might well pause and reflect on the long-term constitutional and political implications of installing a majoritarian system in the Security Council before they endorse a revision which may prove irreversible.

W. Michael Reisman *

\title{
The Case of the Nonpermanent Vacancy
}

Five states are permanent members of the United Nations Security Council." Ten others, characterized in Charter Article 23 as "non-permanent members," are elected by the General Assembly for a term of 2 years; no nonpermanent member may be immediately reelected. ${ }^{3}$ Under Rule 144 of the Assembly's Rules of Procedure, five nonpermanent members are elected each year." Under Rule 85 , election of nonpermanent members is an "important question" requiring a two-thirds majority of Assembly members

"GA Res. 377A (V), Nov. 3, 1950, 5 GAOR, Supp. (No. 20) 10-12.

* This comment draws on work done under a grant from the National Science Foundation. Helpful comments by my colleague, Myres S. MicDougal, are gratefully acknowledged.

"United Nations Charter Article 23(1). Permanent members designated in that provision are the "Republic of China," France, the USSR, the United Kingdom, and the United States.

Article 23(1) establishes qualitative criteria to guide the Assembly in the election of the nompermanent members, the most politically significant being that of geographical distribution. In 1963, Article 23 was amended to expand the number of nonpermanent members from 6 to 11, Sti infra.

'Charter Article 23(2).

" United Nitions, Rules of Procedure of the General Assenbly (1972). 
"present and voting," i.e., "casting an affirmative or negative vote." Voting continues, under Rule 96, until the vacancy is filled. In terms of current numbers, about 50 states (in the rather unusual circumstance in which all Assembly members choose to vote) could prevent the election of one or more nonpermanent members of the Council. There are alreao'y voting blocs that exceed this numerical threshold, likely coalitions of smaller blocs or ad hoc alignments that could attain it, and larger states that, because of their military power, might win over to their view a sufficient number of voters or abstainers. In short, the possibility is not remote that the Security Council could fall below its full complement of nonpermanent members for an extended period of time as a result of a premeditated maneuver by one or more states. The strategic advantages in UN politics that might accrue to the blocking minority will depend in part on the legal consequences attendant on nonpermanent vacancies in the Security Council.

The inability of the General Assembly to fill a vacancy on the Security Council in December 1979 and early January 1980 raised in sharp fashion a number of questions about the competence of a Council whose quantitative composition is or becomes less than the complement designated in the Charter. Cuba and Colombia were competing for the last of the nonpermanent seats - the so-called Latin American seat-on the Council, but neither was able to secure a majority. By December 9 , a record 58 ballots had been cast by 152 members of the General Assembly. ${ }^{6}$ In a ballot on December 17, Cuba failed to win the seat by only 4 votes. ${ }^{7}$ Allegations of fraud were lodged and Under-Secretary General William Buffum was asked to monitor further voting. ${ }^{8}$ By December 29 , the Assembly was still deadlocked. ${ }^{9}$ Hence the Council commenced its meetings in January 1980 short of its full complement for the first time in its history. ${ }^{10}$ But on January 6, Cuba abandoned its effort to obtain the vacant seat, apparently fearing, the New York Times reported, that the Soviet invasion of Afghanistan might result in a landslide of votes for Colombia. ${ }^{11}$ On January 7, Mexico was elected to the vacant seat, after Cuba and Colombia had reached a compromise under the terms of which they would both withdraw. ${ }^{12}$ During the short period of the rump Council, no votes were taken. Hence there is no decisive precedent on the competence of the Council when its designated membership is incomplete. The possibility in the future of such occurrences makes clarification of the law and policy of the matter most urgent.

I.

A jurisprudence, now apparently generally accepted, holds that abstention or withdrawal of a permanent member is neither an automatic veto nor a con-

5 Rule 88, id. at 19.

${ }^{6}$ New York Times, Dec. 10, 1979, at 11, col. 1 .

${ }^{\top} I d$., Dec. 18,1979 , at 8 , col. 6 .

${ }^{9}$ Id., Dec. 30, 1979, at 3, col. 2.

${ }^{8} I d .$, Dec. 20,1979 , at 11 , col. 1 .

${ }^{11}$ Id., Jan. 7, 1980, at 2, col. 3 .

${ }^{10}$ Id., Jan. 1,1980 , at 6 , col. 1 .

${ }^{12}$ Id., Jan. 8, 1980, at 2, col. 3. 
tinuing impediment to Council decision competence. ${ }^{13}$ Is there a comparable rule with regard to nonpermanent members? Specifically, is a Security Council that does not have the requisite number of nonpermanent members to be considered a Council fully competent to discharge all the functions and powers delegated to it by the Charter of the United Nations? Or is it to be considered disabled from applying its powers under the Charter? If it is disabled, how, if at all, will the Charter powers be executed? Given the central role of the Security Council in the maintenance of international peace and security, the answers to these questions are of great political importance.

Vacancies in the Security Council occur for different reasons. A nonpermanent member might withdraw or otherwise lose some membership privileges in the course of its 1-or 2-year tenure; the Council would continue to be depleted, from the moment withdrawal was legally accomplished, until the General Assembly elected and installed a replacement. ${ }^{14}$ Alternatively, the number of nonpermanent members of the Council could be expanded. ${ }^{15}$ In 1963, the Charter was amended to increase, as of 1965 , the number of members of the Security Council from 11 to $15 .^{16}$ In the interim between the moment the Charter amendment went into effect and the moment the General Assembly elected the additional four members, the Council's complement was less than statutorily required. ${ }^{17} \mathrm{~A}$ third vacancy situation, much closer to the one actually presented to the United Nations in year-end 1979, arises when the General Assembly, perhaps unable to reach a majority decision, or animated by a conscious desire on the part of a majority of the Assembly or a blocking minority not to fill the complement of the Security Council, does not designate one or more nonpermanent members; as a result, the Council's number falls below the statutorily required complement.

\section{II.}

On January 2, 1979, the Legal Counsel to the Secretary-General, Erik Suy, presented to the General Assembly an opinion regarding the legal and constitutional consequences that might arise from the inability of the Gen-

\footnotetext{
${ }^{13}$ Stavropoulos, The Practice of Voluntary Abstentions by Permanent Members of the Security Counal under Article 27, paragraph 3 of the Charter of the United Nations, 61 AJIL 744 (1967).

${ }^{14}$ In addition to voluntary withdrawal, a state that, during its nonpermanent incumbency, became a target of United Nations preventive or enforcement action, could suffer suspension of its rights and privileges under Charter Article 5. That might be construed as vacating its place on the Security Council or as suspending its voting right there. But $c f$. L. Goodrich, E. Hambro, \& A. Simons, Charter of the United Nations 97 ( 3 d rev. ed. 1969). Expulsion in accord with Charter Article 6 would most certainly vacate a nonpermanent member's seat on the Security Council.

${ }^{15}$ Sir note 2 supra and also Suy opinion, UN Doc. A/34/PV.118 (prov.) at 31-32 (1979).

${ }^{16}$ GA Res. 1991 (XVIII), Dec. 17, 1963.

${ }^{n}$ A legal opinion by the Legal Counsel of the United Nations on this point stated that in the interim the Security Council would not be prevented from operating: UNrTED NatIons, JuRIDICAL YEARBOOK, 1965, at 224-25.
} 
eral Assembly to elect the full complement of nonpermanent members to the Council. ${ }^{18}$ Suy opined, on the basis of the general principle of effectiveness in treaty interpretation, that despite the fact that the Assembly's obligation to elect the nonpermanent members was absolute, the Assembly's failure to discharge its obligation would not paralyze the Security Council.

[A]n act of omission or the failure of the General Assembly to fulfill its constitutional obligations cannot be held to produce legal consequences so fundamental to the Organization as the paralysis of a principal organ. To argue otherwise would be to effect a constitutional amendment of the Charter through extra-constitutional means. Such a paralysis could have the gravest consequences for the whole system of the preservation of international peace and security, including a potential shift of well-established powers between the Security Council and the General Assembly. ${ }^{19}$

When pressed, the Legal Counsel refrained from elaborating on the consequence of vacancies on the Council's decision competence. As the representative of Guinea-Bissau put it:

Let us assume that within the next ten days the Council meets with 14 members and agrees to impose an embargo, or whatever, on any member state. Would it be legal, or would it be illegal? Would that member have any kind of obligation or any kind of duty to obey the decision of the Council with 14 members?

Though the Legal Counsel did not answer, it would appear that the only conclusion compatible with his general opinion would be that a Security Council, with or without its full complement of nonpermanent members, would have full competence to discharge any of the functions accorded it under the Charter.

III.

The Yalta formula, ${ }^{21}$ which was enshrined in the Charter, assigned decision competence to the Security Council and an essentially hortatory role to the General Assembly. Although a numerical majority of the Council was nonpermanent, the veto privilege locked decisionmaking competence into the hands of the permanent members. Thus, for the rnajor security issues that might come before the Security Council, it was, Charter rhetoric notwithstanding, essentially the great powers that decided.

\footnotetext{
${ }^{18}$ Opinion of Erik Suy, note 15 supra, at 30 et seq.

${ }^{19} I d$. at 36. In Assembly discussion, subsequent to the presentation of the legal opinion, the representative of Guinea-Bissau sought clarification on the minimum numerical requirement: "What would be the minimum requirement? How about 13 members? Or 12, or 11, or 10, or 9 -or only the five permanent members?" $I d$. at 57 . The Legal Counsel did not answer this question, perhaps in response to the signal from the questioner that no answer would satisfy his delegation.

${ }^{20}$ Id. at 37-38.

${ }^{21}$ See U.S. Dep't of State, The Conferences of Malta and Yalta, 1945, at 661-67, 711-12 (1955). See also L. Goodrich, E. Hambro, \& A. Simons, supra note 14, at 216-21, and R. Russell, A History of the United Nations Charter 531-40 (1958).
} 
In the early years, Soviet use of the veto (quite consistent with Charter law, whatever the merits of its exercise in individual cases) prevented the United States and its allies from making the United Nations an effective instrument of diplomacy. Because the United States could then anticipate majority support in the General Assembly, the Department of State, during the tenure of Dean Acheson, initiated the "Uniting for Peace" Resolution. Briefly, it "self-authorized" the General Assembly to exercise some of the security powers of the Council when the latter was blocked.

[I] f the Security Council, because of lack of unanimity of the permanent members, fails to exercise its primary responsibility for the maintenance of international peace and security in any case where there appears to be a threat to the peace, breach of the peace or act of aggression, the General Assembly shall consider the matter immediately with a view to making appropriate recommendations to Members for collective measures, including in the case of a breach of the peace or act of aggression the use of armed force when necessary, to maintain or restore international peace and security. If not in session at the time, the General Assembly may meet in an emergency special session within twenty-four hours of the request therefor. Such emergency special session shall be called if requested by the Security Council on the vote of any seven members, or by a majority of the Members of the United Nations. ${ }^{22}$

From the U.S. perspective, the function of Uniting for Peace was to revise the Security Council's powers by circumventing the Soviet veto.

Uniting for Peace and a number of other developments gradually enhanced the powers of the General Assembly, a development whose lawfulness was confirmed by the International Court of Justice in $1962 .{ }^{23}$ During this same period, the membership in the Assembly increased rapidly, and many of the new' states, variously styled "the Third World, the nonaligned states, the Group of 77," and so on, began to develop an identification distinct from the Western and Eastern blocs. The Third World viewed with considerable satisfaction the en hancing of General Assembly powers in competition with the Security Council. And as the power of the Assembly increased, the United States and the Soviet Union began to vie for influence within the General Assembly. The pattern of change can easily be traced in the evolution of Soviet attitudes regarding the General Assembly's competence. The USSR initially denounced Uniting for Peace, ${ }^{24}$ but by 1967 , it

$\therefore$ GA Res. 377A (V), Nov. 3, 1950, 5 GAOR, Supp. (No. 20) 10-12. Note, however, that the resrilution does not authorize recommending armed force for a threat to the peace but only for a breach of the peace or act of aggression. In contrast, the Security Council retains the option of high coercion as one lawful response to a threat to the peace. The general problem if the legal effect of a resolution of the General Assembly is too complex to be entered into in a froutnote. While it is not binding in the sense of a decision of the Security Council under Articles 25 and 26 of the Charter, it may achieve a certain substantial legal effect depending on the context.

2 Certain Expenses of the United Nations (Article 17, Paragraph 2 of the Charter), [1962] ICJ REP. 151.

24 . grmirally 5 GAOR, 1st Committee, 354th-371st mtgs. (Oct. 9-21, 1950). 
felt sufficiently confident of its influence in the Assembly to initiate a special session itself, invoking the very resolution it had theretofore maligned. ${ }^{25}$

\section{IV.}

With this political background in mind, the significance of the case of the nonpermanent vacancies is apparent. If the Security Council has an inadequate complement and is then authoritatively interpreted as being unable to operate, it no longer means that those powers assigned under the Charter to the Council will simply not be exercised until the Council's complement is filled. What it means is that those powers will devolve to the General Assembly, to be exercised there without regard to the controls the Charter regime had assigned to the permanent members of the Council.

Given the increasingly disproportionate superpower influence in the erstwhile nonaligned world, the practical implication of that interpretation of nonpermanent vacancies is to permit an actor to use the General Assembly to accomplish what it is unable to win in the Security Council. A nonpermanent vacancy could then cease to be an unusual occurrence and become a routine tactic. One great power with a bloc or sufficient ad hoc influence in the Assembly could immobilize the Security Council by impeding the election of a nonpermanent member. It would then be rewarded for its efforts by having Security Council powers devolve to the General Assembly, where their exercise would be insusceptible to veto by another permanent member.

V.

It has become fashionable to criticize the institution of permanent membership and its special perquisites as regressive and undemocratic. The casual use of those terms in the context of international politics skewers and distorts them. Whether or not "one man, one vote" is an inherent principle of democracy (in a pluralistic system, a group of groups, the difficulties and inequities that would flow from its unqualified use are obvious), there is no correspondence between "one man, one vote" and "one state, one vote." If a micro-state of 100,000 and a medium-sized state of 50 million have one vote in a formal arena, every citizen in the micro-state has actually cast five hundred votes vis-à-vis each vote cast by a citizen of the larger state. Nor is there any meaningful democracy when the elites casting a vote "on behalf of" the citizens of their polity are dictatorial with no civic responsibility to their constituents, a situation prevailing in, alas, too many states. The fact that the most vocal critics of the permanent membership and veto institutions are often those who practice the most authoritarian politics must not be ignored. If the rhetoric is scaled off, this, as so many other new maneuvers, is little more than a tactic to aggrandize the power of new elites.

\footnotetext{
${ }^{25}$ See UN Doc. A/6717, letter of June 13, 1967, from the USSR. See also UN Doc. A/6718, letter from the United States expressing reservations regarding Soviet use of L'niting for Peace.
} 
Given the extraordinarily varied circumstances internal to states of the world, the variations of size between them, and the disparate distribution of power among competing major states, a meaningful democratic goal would balance representation in formal arenas with the inexorable requirements of minimum order in an unfantasized world. Before the original Charter regime is radically changed, its conception of and grounding in the realities of power politics should be appreciated. It represents an effort, however imperfect, to seek a meaningful and realistic balance between the desire for power sharing in formal arenas and the unyielding practical restraints of effective power.

In terms of effective power, critical decisions continue to be largely infuenced by a small number of states. If authoritative arenas are to be as effective as possible, they must accommodate themselves to this aspect of political reality. They may work to change it as best they can, but to ignore it simply dooms an arena to a semantic function and ultimately to the withdrawal of support by large powers persuaded that their vital interests can no longer be served by participation in it.

While there is certainly room for an enhancement and clarification of the prescriptive function of the General Assembly, the core distribution of power between the Security Council and the General Assembly with regard to primary security matters is both a fail-safe device for the United Nations and a constant monitor for realism in decision and congruence between authority and control. The most cogent criticism of the implications of the nonpermanent vacancy case is not the formalistic cavil that an unconstitutional amendment was being effected $;^{26}$ international lawmaking is rich in informality and innovation. The problem is the substance of the change and the disruptive, if not destructive, consequences it would have held for the Organization and for its still useful role in world politics.

W. Michael Reisman

\section{CORRESPONDENCE}

The American Journal of International Law welcomes short communications from its readers. It reserves the right to determine which letters shall be published and to edit any letters printed.

To THE EDITORS-IN-ChiEF:

The Iran Hostage Crisis

By way of editorial comment in the April 1980 issue of the Journal (74 AJIL 411), Professor Richard Falk, in his usual provocative manner, suggests that. with respect to the Iran hostage crisis, international law and procedures are "arbitrary and one-sided." He suggests further that we should "not sit too quickly in judgment of Ayatollah Khomeini for his evident refusal to shape Iranian policy by reference to the law on the books," citing in support of this proposition alleged violations of international law

\footnotetext{
Opinion of Erik Suy, note 15 supra, at 36.
} 